\title{
EFFECT OF APELIN-13 ADMINISTRATION ON GASTRIC SECRETION IN NORMAL
} AND DIABETIC RATS

\author{
Akmal A. Diab, Soad A. Ahmed, Abeer A. Khalefa and Reham H. Ibrahim \\ Physiology Department, faculty of medicine, Zagazig University
}

\begin{abstract}
Background: Apelin is a recently discovered peptide, identified as an endogenous ligand of receptor APJ, apelin has beneficial effect in diabetic conditions as it increase glucose uptake and improve insulin sensitivity, diabetic patients have impaired gastric secretion and apelin is expressed in parietal, chief and mucous cells and this raise the possibility of involvement of apelin in gastric physiology.

Objective: The present study was carried out to demonstrate the effect of acute and chronic administration of apelin 13 on gastric secretion in normal and diabetic rats.

Design: 98 adult wistar male albino rats were used, animals were divided into three main groups group A (normal rats), group B (high fat diet induced diabetic rats) and group C (streptozotocin induced diabetic rats), each group is subdivided into control subgroup (1), acute apelin-13 injected subgroup (2), chronic apelin-13 injected subgroup for 21 days (3): In all studied groups, different parameters of gastric secretion, gastric mucosal $\mathrm{pH}$ and mucin content were measured.

Results: acute administration of apelin-13 decreased gastric acid secretion in all groups proved by significant increase in $\mathrm{pH}$ accompanied by significant decrease in total and free acidity, the percentage in decrease of gastric acid secretion in normal rats is more than that of high fat diet induced diabetic rats and streptozotocin induced diabetic rats. Ghrelin level, volume of gastric secretion, blood glucose and HOMA- IR significantly decreased in all groups. pepsin, mucin content of gastric mucosa and insulin level had no significant change in all groups, while, $\mathrm{pH}$ of gastric mucosal surface significantly increased .In addition, there was negative correlation between ghrelin level and $\mathrm{pH}$, positive correlation between ghrelin and both total and free acidity in normal rats, positive correlation between ghrelin and volume of gastric secretion in all studied groups. Chronic administration of apelin-13 caused no change in gastric acidity in normal rats. and increase gastric acidity in high fat diet induced diabetic rats and streptozotocin induced diabetic rats, proved by significant decrease in $\mathrm{pH}$ accompanied by significant increase in total and free acidity, the percentage of increase in gastric acid secretion in high fat diet induced diabetic rats is more than that of streptozotocin induced diabetic rats, moreover, chronic administration of apelin-13decreased ghrelin level, pepsin level, volume of gastric secretion, blood glucose, insulin level and HOMA- IR and increase $\mathrm{pH}$ of gastric mucosal surface and mucin level in all studied groups. In addition, there is positive correlation between ghrelin and volume of gastric secretion in all studied groups.

Conclusion: While apelin-13 injection on chronic run caused no change in gastric acidity in normal rats, it improved gastric acidity in diabetic rats and can act as a promising target for type 2 diabetes treatment. In addition apelin-13 can be considered as gastro protective agent as it increased $\mathrm{pH}$ of gastric mucosal surface and mucin level in normal and diabetic rats.
\end{abstract}

Key words: Apelin, gastric secretion, diabetes.

\section{INTRODUCTION}

A pelin is an adipokine isolated from the bovine stomach(1).Apelin is produced as a 77 amino acid preproprotein that is cleaved into a variety of bioactive forms, each of which retain the C-terminus of the precursor, The C-terminal of apelin constitute the core region essential for apelin function(2,3).The apelin peptides activate the class A G-protein-coupled receptor (GPCR) angiotensin like receptor 1(APJ)(4).A possible role for apelin in gastrointestinal function was implied since apelin was isolated from stomach extracts (5).Immunohistochemical (IHC) studies showed abundant apelin-positive cells in the mucosal epithelium of the stomach, especially in mucous neck cells, parietal cells and chief cells. The localization of apelin in gastric exocrine cells suggests that apelin is secreted into the gastric lumen in response to secretagogues that activate gastric exocrine cells(6). Yakabi et al.(7)and Ohno et al.(8) state that apelin stimulates acid secretion and histamine release in rat stomach, on the contrary, Lambrecht et al.(9)stated that apelin released from parietal cell binds to the APJ receptor expressed in enterochromaffin like cells, thereby inhibiting histamine release and acid secretion in the gastric mucosa.

In diabetic conditions, acid secretion decreased due to autonomic neuropathy (10), caused by insulin deficiency in type 1 diabetes or presence of insulin resistance in type 2 diabetes as insulin is a potent factor that supports neuronal growth and survival $(\mathbf{1 1}, 12,13)$.

In view of all previous reports, this study is designed to explore the effect of acute and chronic administration of apelin-13 on gastric secretion in normal, high fat diet induced diabetic and streptozotocin induced diabetic rats.

\section{MATERIAL AND METHODS}

\section{Animals:}

This study was conducted on 98 adult male healthy albino wistar rats 14 weeks old with body weight 200-230 gm, were obtained from the animal house of faculty of veterinary medicineZagazig University. Rats were kept in steel wire cages (4-6/cage) in the physiology animal house 
in faculty of medicine -Zagazig University under hygienic conditions.

Animals had free access to water, kept at room temperature and were maintained on a $12 \mathrm{~h}$ light/dark cycle.

Rats were divided into three main groups: Group A (normal rats, n= 24), fed ordinary diet, Group B (high fat diet induced diabetic rats "HFD" $\mathrm{n}=35$ ) rats fed high fat diet generally contain protein $20 \%$, carbohydrates $35 \%$ and fat $45 \%$, mainly in form of lard and soy bean for 10 weeks (14), 24 rats which were obese and diabetic were selected and group C (streptozotocin induced diabetic rats, $n=39$ ) injected by single intra-peritoneal injection of freshly prepared solution of streptozotocin (Sigma Aldrich Co.USA) $50 \mathrm{mg} / \mathrm{kg}$ of body weight dissolved in 0.2 $\mathrm{mmol} / \mathrm{L}$ sodium citrate, at $\mathrm{PH} 4.5(\mathbf{1 5})$, rats were given $0.1-0.2 \mathrm{ulkg}$ of insulin by subcutaneous injection daily to prevent ketosis and reduce mortality without normalizing blood glucose level(16) (9 rats died and 24 were selected with high blood glucose levels). Rats were used for the experiment after development of impaired gastric innervation 3 weeks after induction of diabetes (17).

Each group was further subdivided into control subgroup (1): Rats are injected intravenous (i.v) in the rat tail with saline $0.5 \mathrm{ml}$ for 21 days, acute subgroup (2): injected i.v with saline $0.5 \mathrm{ml}$ for 20 days then injected once with apelin13 dissolved in saline, immediately before use (Sigma Aldrich Co.-USA) $20 \mu \mathrm{g} / \mathrm{Kg}$ i.v in the day 21(10), chronic subgroup (3): injected i.v with apelin 13 at a dose of $10 \mathrm{ug} / \mathrm{kg} /$ day for 21 days.

\section{Methods:}

At day 21 of experiment rats were fasted for 12 hours, rats was anaesthetised, using ether, onlyduring the operation, as it was not restrained as awakening to avoid the consequence of restraint on gastric secretion (18).

In all groups, gastric juice was collected by pylorus ligation according to Alumets et al.(18), it was collected after 1 hour of pylorus ligation(8), stomach was removed and washed by distilled water, gastric mucosal $\mathrm{pH}$ was measured with an indicator paper ( $\mathrm{pH}$ fix 0-14 Art N 92100, Machoney Nagel GmBh Duren. Germany), then stomach was kept in Formaldehyde and prepared for acian blue staining of mucin content as described by Bancroft and Stevens,(19). Gastric juice was centrifuged and examined for:

PH of the gastric secretion was determined by using $\mathrm{pH}$ meter. total acidity and free acidity was measured by Hawk et al. (20).
Ghrelin level was measured according to the method by Kojima et al. (21).

Pepsin was measured according to the method by Debanth et al (22).

The volume was estimated by measuring pipettes. After collection of gastric juice and removal of the stomach, the blood samples were obtained from all rats by scarification. Serum was separated by centrifugation of blood at $3000 \mathrm{rpm}$ for 15 minutes and examined for:

Serum glucose level: According to Tietz et al. (23) using glucose enzymatic (GOD-PAP)liquizyme Kits (Biotechnology, Egypt).

Serum insulin level: By a solid phase enzyme amplified sensitivity immunoassay according to Temple et al. (24) using KAP1251-INS-EASIA (Enzyme Amplified Sensitivity Immunoassay) Kits (BioSource Europe S.A., Belgium).

HOMA-IR was assessed by homeostasis model assessment (where HOMA = fasting serum insulin $(\mu \mathrm{IU} / \mathrm{mL}) \quad \mathrm{x}$ [fasting serum glucose $(\mathrm{mmol} / \mathrm{L}) / 22.5](\mathbf{2 5}, \mathbf{2 6})$.

The data obtained in the present study were expressed as mean \pm SD for quantitative variables and statistically analyzed by using SPSS program (version 18 for windows) (SPSS Inc. Chicago, IL, USA). P value $<0.05$ was considered statistically significant.

\section{RESULTS}

Table 1: shows the effect of acute and chronic administration of apelin-13 on all parameters measured in the normal rats: (control group; A1) (acute apelin-13 treated group; A2), (chronic apelin-13 treated group; A3).

It was found that acute administration of apelin13 in group A2 resulted in significant increase in the mean values of $\mathrm{pH}$ of gastric secretion and gastric surface $\mathrm{pH}(4.03 \pm 0.84, \quad 8.12 \pm 0.83$ respectively) in comparison with that of control group (A1) $(2.29 \pm 0.28,7.37 \pm 0.51$ respectively) ( $\mathrm{P}<0.001, \quad \mathrm{P}<0.05$ respectively), accompanied by significant decrease in the mean values of ghrelin level, total acidity, free acidity, volume of gastric secretion, serum glucose, HOMA-IR $(40.2 \pm 5.5,59 \pm 5.98,34.2 \pm 6.8, \quad 0.68 \pm 0.24$, $66.5 \pm 12.4, \quad 3.4 \pm 0.62$ respectively) in comparison with that of control group(A1) (55.9 \pm $6.6,81.02 \pm 1.9,52.9 \pm 1.7,1.36 \pm 0.3,89.6 \pm$ $16.9,4.7 \pm 1.2$ respectively) (P values: $\mathrm{P}<0.001$, $\mathrm{P}<0.001, \mathrm{P}<0.001, \mathrm{P}<0.001$ and $\mathrm{P}<0.01$ respectively). However, there was no significant change in the mean values of pepsin level or serum insulin level $(3.12 \pm 0.48,20.7 \pm 2.4$ respectively) in comparison with that of control group (A1) $(3.22 \pm 0.48,21.04 \pm 2.6)(\mathrm{P}>0.05)$. 
As regard chronic administration of apelin-13 in group A3 there was significant increase in the mean values of gastric surface $\mathrm{pH}(8.5 \pm 0.53)$ in comparison with that of control group(A1) $(7.37 \pm$ $0.51)$ ( $\mathrm{P}<0.01)$, accompanied by significant decrease in the mean value of ghrelin level, pepsin level, volume of gastric secretion, serum glucose level, serum insulin level, HOMA-IR (37.1 \pm 7.4, $2.1 \pm 0.56,0.49 \pm 0.25,70.7 \pm 14.6,15.3 \pm 2.3,2.7$ \pm 0.88 respectively) in comparison with that of control group (A1) $(\mathrm{P}<0.001, \mathrm{P}<0.01, \mathrm{P}<$ $0.001, \mathrm{P}<0.05, \mathrm{P}<0.01$ and $\mathrm{P}<$ 0.001 respectively). However, there was no significant change in the mean values of $\mathrm{pH}$, total acidity, free acidity $(2.04 \pm 0.42,88.8 \pm 12.3,59.9 \pm$ 11.2 respectively) in comparison with that of control group(A1) (P > 0.05).

In addition, there is significant negative correlation between ghrelin level and $\mathrm{pH}$ in both control group A1) and acute group (A2) ( - 0.93, P $<0.01 \&-0.83, \mathrm{P}<0.05$ respectively), accompanied by significant positive correlation between ghrelin and both total acidity and free acidity in control group(A1) $(0.98,(\mathrm{P}<0.05) \&$ $0.97,(\mathrm{P}<0.01)$ respectively $)$ and acute $\operatorname{group}(\mathrm{A} 2)$ ) $(0.8, \mathrm{P}<0.05 \& 0.87, \mathrm{P}<0.01)$, significant positive correlation between ghrelin and volume of gastric secretion in all groups $(0.92, \mathrm{P}<0.01 \&$ $0.72, \mathrm{P}<0.05 \& 0.77, \mathrm{P}<0.05$ respectively).

Table 2 shows the effect of acute and chronic administration of apelin-13 on all parameters measured in High fat diet (HFD) induced diabetic rats: (control group B1) (acute apelin-13 treated group; B2), (chronic apelin-13 treated group; B3).

It was found that acute administration Of apelin13 in group B2 resulted in significant increase in the mean values of $\mathrm{pH}$ of gastric secretion and gastric surface $\mathrm{pH}(5.2 \pm 0.77,6.75 \pm 0.46$ respectively) in comparison with that of control group (B1) $(4.05 \pm 0.7, \quad 8,6 \pm 0.75$ respectively) $(\mathrm{P}<0.05)$. Accompanied by significant decrease in the mean values of ghrelin level, total acidity, free acidity, volume of gastric secretion, serum glucose, HOMA-IR $(30.49 \pm 3.94, \quad 34.7 \pm 4.2$, $25.1 \pm 2.5, \quad 0.46 \pm 0.2,158 \pm 19.8,15.1 \pm 3.15$ respectively) in comparison with that of control group (B1) $(35.9 \pm 4.9, \quad 39.9 \pm 4.3,33.2 \pm 6.7$, $0.83 \pm 0.1, \quad 210 \pm 24.5,21.2 \pm 3.8$ respectively) $(\mathrm{P}<0.05, \mathrm{P}<0.05, \mathrm{P}<0.05, \mathrm{P}<0.01, \mathrm{P}<0.05$, $\mathrm{P}<0.001$ respectively). However, there was no significant change in the mean values of pepsin and serum insulin $(3.11 \pm 0.81, \quad 38.13 \pm$ 4.5respectively) in comparison with that of

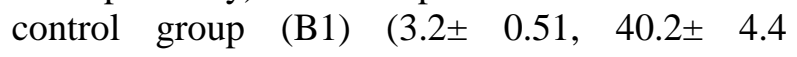
respectively $),(\mathrm{P}>0.05)$.
As regard chronic administration of apelin-13 in group B3 there was significant increase in the mean value of total acidity, free acidity, gastric surface $\mathrm{pH}(49.1 \pm 2.7,39.3 \pm 4.7,6.87 \pm 0.36$ respectively) in comparison with that of control group (B1) $(\mathrm{P}<0.05, \mathrm{P}<0.05, \mathrm{P}<0.01$ respectively). Accompanied by significant decrease in the mean value of ghrelin level, $\mathrm{pH}$, pepsin level, volume of gastric secretion, serum glucose level, serum insulin level, HOMA-IR $(29.7 \pm 4.8,3.3 \pm 0.48,2.47 \pm 0.15,0.44 \pm 0.26$, $138.1 \pm 10.6,29.2 \pm 3.4,10.09 \pm 1.35$ respectively) in comparison with that of control group (B1) (P< $0.05, \mathrm{P}<0.05, \mathrm{P}<0.05, \mathrm{P}<0.01, \mathrm{P}<0.001, \mathrm{P}<$ $0.001, \mathrm{P}<0.001$ respectively).

In addition, there is significant positive correlation between ghrelin and volume of gastric secretion in all groups $(0.76, \mathrm{P}<0.05 \& 0.77, \mathrm{P}<$ $0.05 \& 0.75, \mathrm{P}<0.05$ respectively).

Table 3: shows the effect of acute and chronic administration of apelin-13 on all parameters measured in streptozotocin induced diabetic rats: (control group; C1), (acute apelin-13 treated group; C2), (chronic apelin-13 treated group; C3).

It was found that acute administration of apelin13 in group C2 resulted in significant increase in the mean values of $\mathrm{pH}$ of gastric secretion and gastric surface $\mathrm{pH}(5.3 \pm \quad 0.54,6.62 \pm 0.51$ respectively) in comparison with that of control group $(\mathrm{C} 1)(4.09 \pm 0.17,5.87 \pm 0.83$ respectively) $(\mathrm{P}<0.001, \mathrm{P}<0.05$ respectively). Accompanied by significant decrease in the mean values of ghrelin level, total acidity, free acidity, volume of gastric secretion, serum glucose, HOMA-IR (37.4 \pm 3.9, $37.3 \pm 2.9,23.47 \pm 2.3,0.54 \pm 0.21,338.6 \pm 74.5$, $0.86 \pm 0.45$ respectively) in comparison with that of control group (C1) $(42.3 \pm 3.2,43.1 \pm 2$, $30.7 \pm 2.1,0.91 \pm 0.23,451.8 \pm 99.2,1.7 \pm 1$ respectively) $(\mathrm{P}<0.05, \mathrm{P}<0.05, \mathrm{P}<0.01, \mathrm{P}<$ $0.01, \mathrm{P}<0.05, \mathrm{P}<0.05$ respectively) . However, there was no significant change in the mean values of pepsin level and serum insulin level $(2.75 \pm 0.44, \quad 1.2 \pm 0.53$ respectively) in comparison with that of control group (C1) $(2.8 \pm$ $0.15,1.4 \pm 0.62),(\mathrm{P}>0.05)$.

As regard chronic administration of apelin-13 in group C3 there was significant increase in the mean values of total acidity, free acidity, gastric surface $\mathrm{pH}(48.3 \pm 6.3, \quad 34.7 \pm 5.2,6.75 \pm 0.7$ respectively) in comparison with that of control group $(\mathrm{C} 1)(43.1 \pm 2,30.7 \pm 2.1,5.87 \pm 0.83$ respectively $),(\mathrm{P}<0.05)$. Accompanied by significant decrease in the mean values of ghrelin level, $\mathrm{pH}$, pepsin level, volume of gastric

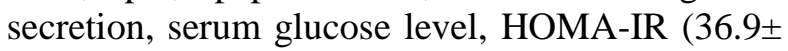
$4.3,3.57 \pm 0.37,2.13 \pm 0.140,0.54 \pm 0.21$, 
$321.6 \pm \quad 69.9, \quad 0.85 \pm 0.45$ respectively) in comparison with that of control group (C1) (P < $0.05, \mathrm{P}<0.05, \mathrm{P}<0.001, \mathrm{P}<0.01, \mathrm{P}<0.01, \mathrm{P}<$ 0.05 respectively). However, there was no significant change in the mean value of serum insulin $(1.02 \pm 0.45)$ in comparison with that of control group $(\mathrm{C} 1)$, $(\mathrm{P}>0.05)$. In addition, there was significant positive correlation between ghrelin and volume of gastric secretion in all groups $(0.75, \mathrm{P}<0.05 \& 0.72, \mathrm{P}<0.05 \& 0.87, \mathrm{P}<$ 0.01 respectively).

Table 1: The effect of acute and chronic administration of apelin-13 on all parameters measured in the normal rats, (control: group A1, acute apelin-13 injected group: A2, and chronic apelin-13 injected group: A3).

\begin{tabular}{|c|c|c|c|c|}
\hline parameter & $(n=8)$ & Group A1 & Group A2 & Group A3 \\
\hline \multirow{2}{*}{$\begin{array}{l}\text { Ghrelint } \\
(\text { pg\ml ) }\end{array}$} & & $55.9 \pm 6.6$ & $40.2 \pm 5.5$ & $37.1 \pm 7.4$ \\
\hline & $\mathrm{p}$ & & $\mathrm{P}<0.001^{\mathrm{a}}, \quad \mathrm{NS}^{\mathrm{c}}$ & $\mathrm{P}<0.001^{\mathrm{a}}, \mathrm{NS}^{\mathrm{b}}$ \\
\hline \multirow{4}{*}{$\mathrm{pH}$} & $\overline{\bar{X}} \pm \mathrm{SD}$ & $2.29 \pm 0.28$ & $4.03 \pm 0.84$ & $2.04 \pm 0.42$ \\
\hline & $\mathrm{p}$ & & $\mathrm{P}<0.001^{\mathrm{a}, \mathrm{c}}$ & $\mathrm{NS}^{\mathrm{a}}, \quad \mathrm{P}<0.001^{\mathrm{b}}$ \\
\hline & $\%$ of change & & +75.9 & -10.9 \\
\hline & $\mathrm{r}$ & $-0.93(\mathrm{P}<0.01)$ & $-0.83(\mathrm{P}<0.05)$ & $-0.26 \mathrm{NS}$ \\
\hline \multirow{4}{*}{$\begin{array}{l}\text { Total } \\
\text { acidity } \\
(\mathrm{mmol} / \mathrm{L})\end{array}$} & $\overline{\mathrm{X}} \pm \mathrm{SD}$ & $81.02 \pm 1.9$ & $59 \pm 5.98$ & $88.8 \pm 12.3$ \\
\hline & $\mathrm{p}$ & & $\mathrm{P}<0.001^{\mathrm{a}, \mathrm{c}}$ & $\mathrm{NS}^{\mathrm{a}}, \mathrm{P}<0.001^{\mathrm{b}}$ \\
\hline & $\%$ of change & & 27.17 & +9.6 \\
\hline & $\mathrm{r}$ & $0.98(\mathrm{P}<0.05)$ & $0.8(\mathrm{P}<0.05)$ & $0.04 \mathrm{NS}$ \\
\hline \multirow{4}{*}{$\begin{array}{l}\text { Free acidity } \\
(\mathrm{mmol} / \mathrm{L})\end{array}$} & $\overline{\mathrm{X}} \pm \mathrm{SD}$ & $52.9 \pm 1.7$ & $34.2 \pm 6.8$ & $59.9 \pm 11.2$ \\
\hline & $\mathrm{p}$ & & $\mathrm{P}<0.001^{\mathrm{a}, \mathrm{c}}$ & $\mathrm{NS}^{\mathrm{a}}, \mathrm{P}<0.001^{\mathrm{b}}$ \\
\hline & $\%$ of change & & -35.3 & +13.23 \\
\hline & $\mathrm{r}$ & $0.97(\mathrm{P}<0.01)$ & $0.87(\mathrm{P}<0.01)$ & $0.22 \mathrm{NS}$ \\
\hline \multirow{3}{*}{$\begin{array}{l}\text { Pepsin } \\
(\mathrm{ng} / \mathrm{ml})\end{array}$} & $\overline{\bar{X}} \pm \mathrm{SD}$ & $3.22 \pm 0.48$ & $3.12 \pm 0.48$ & $2.1 \pm 0.56$ \\
\hline & $\mathrm{p}$ & & $\mathrm{NS}^{\mathrm{a}}, \mathrm{P}<0.001^{\mathrm{c}}$ & $\mathrm{P}<0.01^{\mathrm{a}}, \mathrm{P}<0.001^{\mathrm{b}}$ \\
\hline & $\mathrm{r}$ & $0.21 \quad \mathrm{NS}$ & $0.42 \quad \mathrm{NS}$ & $0.16 \quad \mathrm{NS}$ \\
\hline \multirow{3}{*}{$\begin{array}{l}\text { Gastric } \\
\text { Surface pH }\end{array}$} & $\overline{\mathrm{X}} \pm \mathrm{SD}$ & $7.37 \pm 0.51$ & $8.12 \pm 0.83$ & $8.5 \pm 0.53$ \\
\hline & $\mathrm{p}$ & & $\mathrm{P}<0.05^{\mathrm{a}} \quad, \mathrm{NS}^{\mathrm{c}}$ & $\mathrm{P}<0.01^{\mathrm{a}} \quad, \mathrm{NS}^{\mathrm{b}}$ \\
\hline & $\mathrm{r}$ & $0.72(\mathrm{P}<0.01)$ & $0.13 \mathrm{NS}$ & $0.68 \mathrm{NS}$ \\
\hline \multirow{3}{*}{$\begin{array}{l}\text { Volume } \\
(\mathrm{ml} / 100 \\
\mathrm{gm})\end{array}$} & $\overline{\mathrm{X}} \pm \mathrm{SD}$ & $1.36 \pm 0.3$ & $0.68 \pm 0.24$ & $0.49 \pm 0.25$ \\
\hline & $\mathrm{p}$ & & $\mathrm{P}<0.001^{\mathrm{a}} \quad, \mathrm{NS}^{\mathrm{c}}$ & $\mathrm{P}<0.001^{\mathrm{a}} \quad, \mathrm{NS}^{\mathrm{b}}$ \\
\hline & $\mathrm{r}$ & $0.92(\mathrm{P}<0.01)$ & $0.72(\mathrm{P}<0.05)$ & $0.77(\mathrm{P}<0.05)$ \\
\hline \multirow{2}{*}{$\begin{array}{l}\text { Glucose } \\
(\mathrm{mg} / \mathrm{dl})\end{array}$} & $\overline{\mathrm{X}} \pm \mathrm{SD}$ & $89.6 \pm 16.9$ & $66.5 \pm 12.4$ & $70.7 \pm 14.6$ \\
\hline & $\mathrm{p}$ & & $\mathrm{P}<0.01^{\mathrm{a}} \quad, \mathrm{NS}^{\mathrm{c}}$ & $\mathrm{P}<0.05^{\mathrm{a}}, \mathrm{NS}^{\mathrm{b}}$ \\
\hline \multirow{2}{*}{$\begin{array}{l}\text { Insulin } \\
\text { (u IU/ml) }\end{array}$} & $\bar{X} \pm \mathrm{SD}$ & $21.04 \pm 2.6$ & $20.7 \pm 2.4$ & $15.3 \pm 2.3$ \\
\hline & $\mathrm{p}$ & & $\mathrm{NS}^{\mathrm{a}} \quad, \mathrm{P}<0.01^{\mathrm{c}}$ & $\mathrm{P}<0.01^{\mathrm{a}}, \mathrm{P}<0.001^{\mathrm{b}}$ \\
\hline \multirow{2}{*}{ HOMA-IR } & $\overline{\bar{X}} \pm \mathrm{SD}$ & $4.7 \pm 1.2$ & $3.4 \pm 0.62$ & $2.7 \pm 0.88$ \\
\hline & $\mathrm{p}$ & & $\mathrm{P}<0.01^{\mathrm{a}} \quad, \mathrm{NS}^{\mathrm{c}}$ & $\mathrm{P}<0.001^{\mathrm{a}}, \mathrm{NS}^{\mathrm{b}}$ \\
\hline $\begin{array}{l}\mathbf{a}=\mathrm{VS} \text { grou } \\
\mathbf{r}=\text { correlatio }\end{array}$ & 1 & $\mathbf{b}=\mathbf{V S}$ & $\begin{array}{l}\text { A2 } \\
\text { non significant }(P>\end{array}$ & $\operatorname{roup} \mathrm{A3}$ \\
\hline
\end{tabular}


Table 2: The effect of acute and chronic administration of apelin 13 on all parameters measured in the High fat diet (HFD) induced diabetic rats: (control: group B1, acute apelin-13 injected group: B2, and chronic apelin-13 injected group: B3).

\begin{tabular}{|c|c|c|c|c|}
\hline parameter & $(\mathrm{n}=8)$ & Group B1 & Group B2 & Group B3 \\
\hline \multirow{2}{*}{$\begin{array}{l}\text { Ghrelin } \\
(\mathrm{pg} \backslash \mathrm{ml})\end{array}$} & $\overline{\mathrm{X}} \pm \mathrm{SD}$ & $35.9 \pm 4.9$ & $30.49 \pm 3.94$ & $29.7 \pm 4.8$ \\
\hline & $\mathrm{p}$ & & $\mathrm{P}<0.05^{\mathrm{a}}, \mathrm{NS}^{\mathrm{c}}$ & $\mathrm{P}<0.05^{\mathrm{a}}, \mathrm{NS}^{\mathrm{b}}$ \\
\hline \multirow{4}{*}{$\mathrm{pH}$} & $\overline{\mathrm{X}} \pm \mathrm{SD}$ & $4.05 \pm 0.78$ & $5.2 \pm 0.77$ & $3.3 \pm 0.48$ \\
\hline & $\mathrm{p}$ & & $\mathrm{P}<0.05^{\mathrm{a},}, \mathrm{P}<0.001^{\mathrm{c}}$ & $\mathrm{P}<0.05^{\mathrm{a},}, \mathrm{P}<0.001^{\mathrm{b}}$ \\
\hline & $\%$ of change & & +28.39 & -18.5 \\
\hline & $\mathrm{r}$ & $-0.28 \mathrm{NS}$ & $-0.61 \mathrm{NS}$ & $-0.46 \mathrm{NS}$ \\
\hline \multirow{4}{*}{$\begin{array}{l}\text { Total } \\
\text { acidity } \\
(\mathrm{mmol} / \mathrm{L})\end{array}$} & $\overline{\mathrm{X}} \pm \mathrm{SD}$ & $39.9 \pm 4.3$ & $34.7 \pm 4.2$ & $49.1 \pm 2.7$ \\
\hline & $\mathrm{p}$ & & $\mathrm{P}<0.05^{\mathrm{a},}, \mathrm{P}<0.001^{\mathrm{c}}$ & $\mathrm{P}<0.05^{\mathrm{a},}, \mathrm{P}<0.001^{\mathrm{b}}$ \\
\hline & $\%$ of change & & -13.03 & +23.05 \\
\hline & $\mathrm{r}$ & $0.19 \mathrm{NS}$ & $0.64 \mathrm{NS}$ & $0.32 \quad \mathrm{NS}$ \\
\hline \multirow{4}{*}{$\begin{array}{l}\text { Free acidity } \\
(\mathrm{mmol} / \mathrm{L})\end{array}$} & $\overline{\mathrm{X}} \pm \mathrm{SD}$ & $33.2 \pm 6.7$ & $25.1 \pm 2.5$ & $39.3 \pm 4.7$ \\
\hline & $\mathrm{p}$ & & $\mathrm{P}<0.05^{\mathrm{a},}, \mathrm{P}<0.001^{\mathrm{c}}$ & $\mathrm{P}<0.05^{\mathrm{a},}, \mathrm{P}<0.001^{\mathrm{b}}$ \\
\hline & $\%$ of change & & -24.13 & +18.37 \\
\hline & $\mathrm{r}$ & $0.33 \mathrm{NS}$ & $0.55 \mathrm{NS}$ & $0.16 \mathrm{NS}$ \\
\hline \multirow{3}{*}{$\begin{array}{l}\text { Pepsin } \\
(\mathrm{ng} / \mathrm{ml})\end{array}$} & $\overline{\bar{X}_{ \pm S D}}$ & $3.2 \_ \pm 0.51$ & $3.11 \pm 0.81$ & $2.47 \pm 0.15$ \\
\hline & $\bar{p}$ & & $\mathrm{NS}^{\mathrm{a}}, \mathrm{P}<0.01^{\mathrm{c}}$ & $\mathrm{P}<0.05^{\mathrm{a}}, \mathrm{P}<0.01^{\mathrm{b}}$ \\
\hline & $\mathrm{r}$ & $-0.16 \mathrm{NS}$ & $-0.7 \mathrm{NS}$ & $-0.48 \mathrm{NS}$ \\
\hline \multirow{3}{*}{$\begin{array}{l}\text { Gastric } \\
\text { Surface } \mathrm{pH}\end{array}$} & $\overline{\mathrm{X}} \pm \mathrm{SD}$ & $6 \pm 0.75$ & $6.75 \pm 0.46$ & $6.87 \pm 0.36$ \\
\hline & $\mathrm{p}$ & & $\mathrm{P}<0.05^{\mathrm{a}}, \mathrm{NS}^{\mathrm{c}}$ & $\mathrm{P}<0.01^{\mathrm{a}}, \mathrm{NS}^{\mathrm{b}}$ \\
\hline & $\bar{r}$ & $0.72(\mathrm{P}<0.05)$ & $0.25 \mathrm{NS}$ & $0.28 \mathrm{NS}$ \\
\hline \multirow{3}{*}{$\begin{array}{l}\text { Volume } \\
(\mathrm{ml} / 100 \\
\mathrm{gm})\end{array}$} & $\overline{\mathrm{X}} \pm \mathrm{SD}$ & $0.83 \pm 0.1$ & $0.46 \pm 0.2$ & $0.44 \pm 0.26$ \\
\hline & $\mathrm{p}$ & & $\mathrm{P}<0.01^{\mathrm{a}}, \mathrm{NS}^{\mathrm{c}}$ & $\mathrm{P}<0.01^{\mathrm{a}}, \mathrm{NS}^{\mathrm{b}}$ \\
\hline & $\mathrm{r}$ & $0.76(\mathrm{P}<0.05)$ & $0.77(\mathrm{P}<0.05)$ & $0.75(\mathrm{P}<0.05)$ \\
\hline \multirow{2}{*}{$\begin{array}{l}\text { Glucose } \\
(\mathrm{mg} / \mathrm{dl})\end{array}$} & $\overline{\mathrm{X}} \pm \mathrm{SD}$ & $210 \pm 24.5$ & $158 \pm 19.8$ & $138.1 \pm 10.6$ \\
\hline & $\mathrm{p}$ & & $\mathrm{P}<0.05^{\mathrm{a}}, \mathrm{P}<0.001^{\mathrm{c}}$ & $\mathrm{P}<0.001^{\mathrm{a}}, \mathrm{P}<0.001^{\mathrm{b}}$ \\
\hline \multirow{2}{*}{$\begin{array}{l}\text { Insulin } \\
\text { (u IU/ml) }\end{array}$} & $\overline{\mathrm{X}} \pm \mathrm{SD}$ & $40.2 \_ \pm 4.4$ & $38.13 \pm 4.5$ & $29.2 \pm 3.4$ \\
\hline & $\mathrm{p}$ & & $\mathrm{NS}^{\mathrm{a}}, \mathrm{P}<0.001^{\mathrm{c}}$ & $\mathrm{P}<0.001^{\mathrm{a}, \mathrm{b}}$ \\
\hline \multirow{2}{*}{ HOMA-IR } & $\overline{\bar{X}} \pm \mathrm{SD}$ & $21.2 \pm 3.8$ & $15.1 \pm 3.15$ & $10.09 \pm 1.35$ \\
\hline & $\bar{p}$ & & $\mathrm{P}<0.001^{\mathrm{a}}, \mathrm{P}<0.05^{\mathrm{c}}$ & $\mathrm{P}<0.001^{\mathrm{a}}, \mathrm{P}<0.05^{\mathrm{b}}$ \\
\hline $\begin{array}{l}a=\text { VS grou } \\
\text { NS = non si }\end{array}$ & ificant $(P>0$ & $\begin{array}{r}b=V S \\
r=\text { correlat }\end{array}$ & $\begin{array}{lr}\text { up B2 } & c= \\
\text { with ghrelin levels in th }\end{array}$ & $\begin{array}{l}\text { up B3 } \\
\text { group }\end{array}$ \\
\hline
\end{tabular}


Table 3: The effect of acute and chronic administration of apelin 13 on all parameters measured in streptozotocin induced diabetic rats: (control: group $\mathrm{C} 1$, acute apelin-13 injected group: $\mathrm{C} 2$, and chronic apelin-13 injected group: C3).

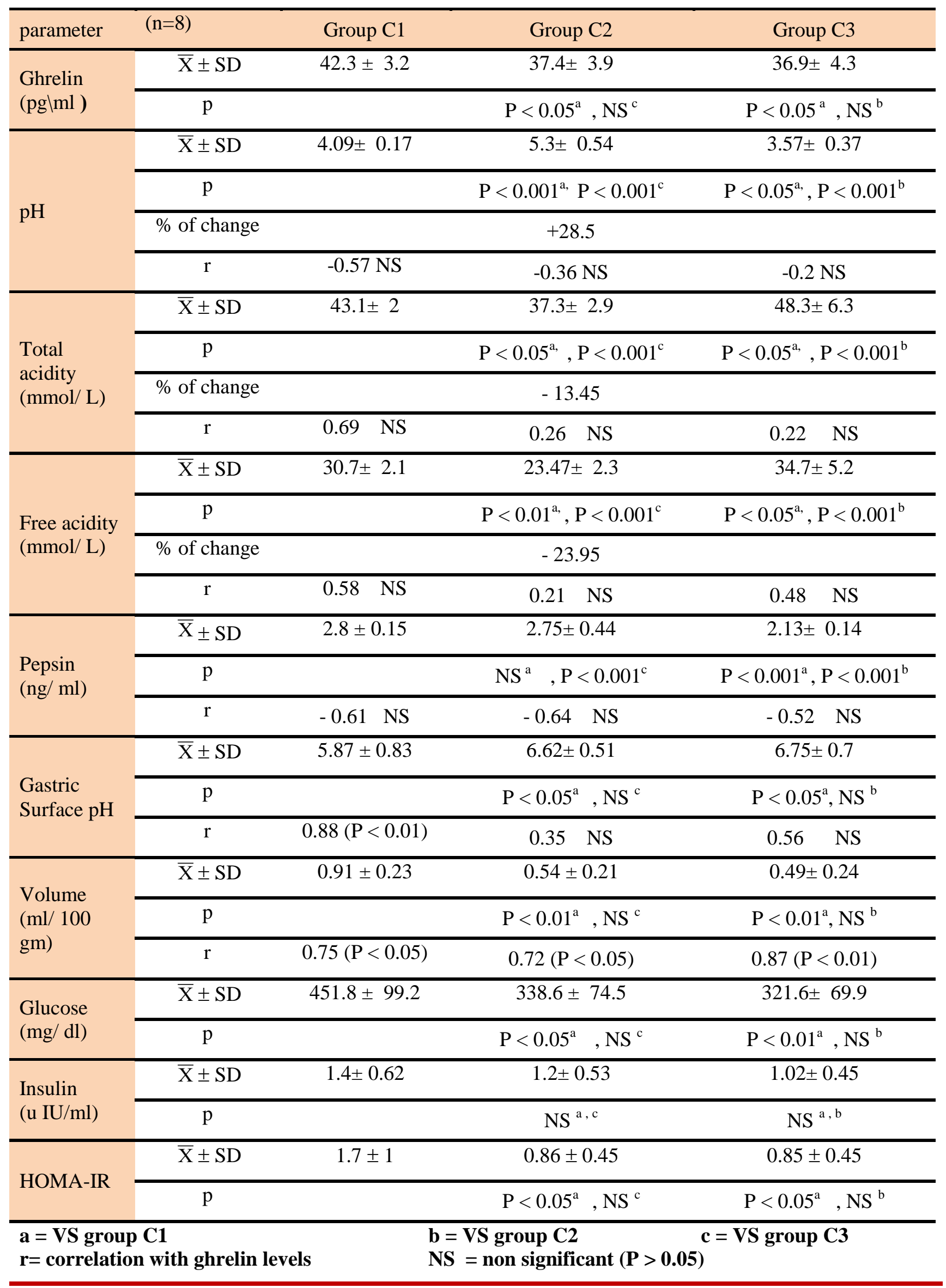



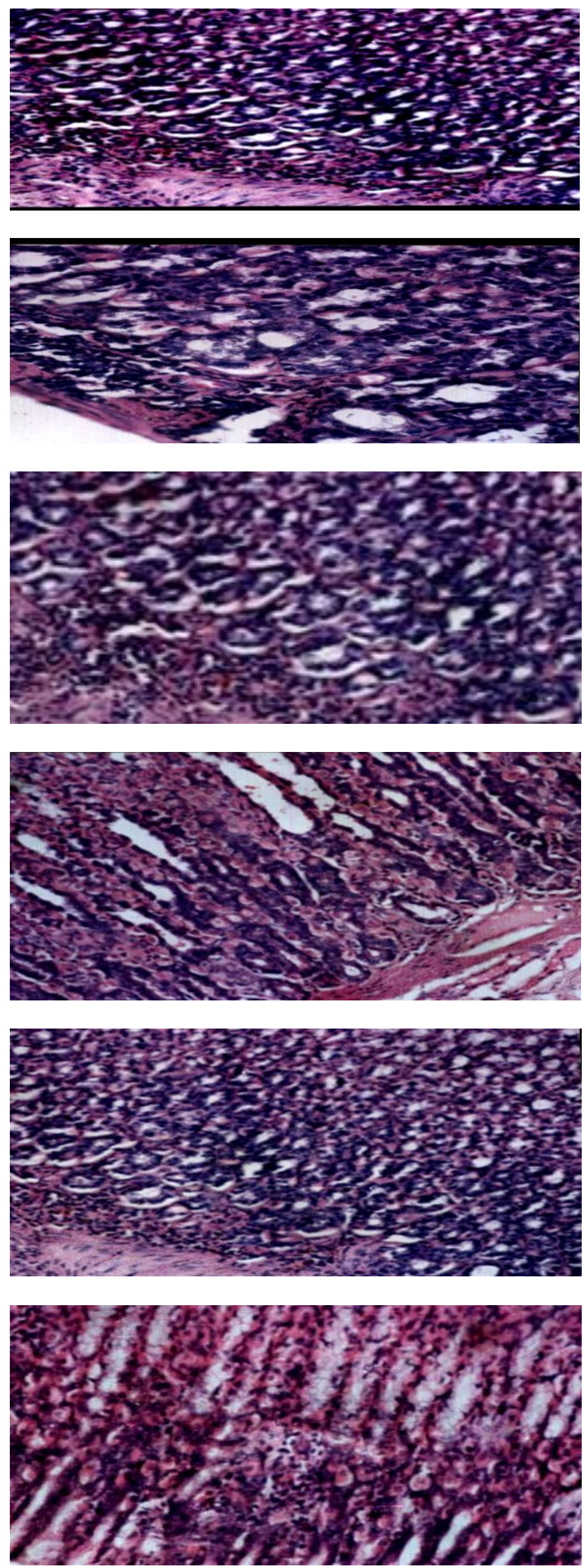

Photo1: Photomicrograph of gastric mucosal gland showing acute effect of apelin-13 $(20 \mathrm{ug} \mathrm{kg}$ i.v) on mucin content in normal rats; there is normal mucin content of the epithelial cells (acian blue -150).

Photo2: Photomicrograph of gastric mucosal gland showing chronic effect of apelin-13 (10 $\mathrm{ug} \backslash \mathrm{kg} \backslash$ day i.v for 21 days) on mucin content in normal rats; there is marked increase in mucin content of the epithelial cells(acian blue-150).

Photo 3: Photomicrograph of gastric mucosal gland showing acute effect of apelin-13 $(20 \mathrm{ug} \mathrm{kg}$ i.v) on mucin content in HFD induced diabetic rats; there is normal mucin content of the epithelial cells(acian blue-150).

Photo 4: Photomicrograph of gastric mucosal gland showing chronic effect of apelin $(10 \mathrm{ug} /$ $\mathrm{kg} \backslash$ day i.v for 21 days) on mucin content in HFD induced diabetic rats there is moderate increase in mucin content of the epithelial cells(acian blue-150).

Photo 5: Photomicrograph of gastric mucosal gland showing acute effect of apelin $(20 \mathrm{ug} \backslash \mathrm{kg} \backslash$ day i.V) on mucin content in streptozotocin induced diabetic rats there is normal mucin content of the epithelial cells(acian blue-150).

Photo 6: Photomicrograph of gastric mucosal gland showing chronic effect of apelin $(10 \mathrm{ug} /$ $\mathrm{kg} \backslash$ day i.V for 21 days) on mucin content in streptozotocin induced diabetic rats there is moderate increase in mucin content of the epithelial cells(acian blue-150). 


\section{DISCUSSION}

Apelin and its receptor APJ constitute a new peptide system with important physiological and pathophysiological roles (27). Apelin was found in the gastric wall, especially in the oxyntic mucosa (28), with highest expression in the fundus of the stomach (6), it is also detected in mucous neck cells and chief cells(29).The previous data suggest physiological roles for apelin in the regulation of gastric function $(\mathbf{6 , 9 )}$. Therefore, the present study demonstrated the effect of acute and chronic administration of apelin-13 on gastric secretion in three groups of adult male wistar albino rats (normal rats, HFD induced diabetic rats and streptozotocin induced diabetic rats).

This study revealed that acute administration of apelin-13in normal, HFD induced diabetic and streptozotocin induced diabetic rats decreased gastric acid secretion proved by significant increase in $\mathrm{pH}$ accompanied by significant decrease in both total and free acidity, this effect may be through different mechanisms ; first, decrease ghrelin content in gastric secretion which is proved in the present study as acute iv administration of apelin 13 in the three groups of rats decrease significantly ghrelin content of gastric secretion, and there was negative correlation between ghrelin level and $\mathrm{pH}$, and positive correlation between ghrelin level and both total and free acidity. Ghrelin was known to stimulate the secretion of gastric acid when administered peripherally or centrally $(\mathbf{3 0}, \mathbf{3 1})$, through vagal nerve stimulation (30).

Second, decrease histamine release from ECL , and this mechanism supported by Lambrecht et al.(9) who reported that while apelin is expressed by parietal cell (PC) but not ECL cells. APJ receptor is expressed in ECL cells but not in PC. In addition, apelin was shown to inhibit intracellular calcium signaling in gastrinstimulated isolated rat ECL cells and suppress the release of histamine (9), which is known by increasing gastric acid secretion and acting as a paracrine stimulant of parietal cells $(\mathbf{3 2 , 3 3 )}$.

Third, apelin increase NO synthesis which in turn decrease gastric acid secretion, this explanation is supported by the studies of Alan et al.(34) and Pisarenko et al. (35) who stated that apelin increase expression of NOS and endothelial NO generation, the latter has inhibitory effect on acid secretion both in vivo and in vitro $(\mathbf{3 6}, 37,38,39,40)$, and decrease histamine release from ECL(41).

However, in both of HFD and streptozotocin induced diabetic rats, acute administration of apelin-13 caused significant decrease in ghrelin, but in both conditions the decreased ghrelin has little importance due to autonomic neuropathy in diabetic rats(10) which prevent the action of ghrelin on vagus nerve (30), this explain that percentage of decrease of gastric acid secretion in normal rats is more than that of HFD and streptozotocin induced diabetic rats due to the additive effect of decreased ghrelin.

Our results in normal rats are different from what stated by Yakabi et al. (7) that iv injection of AP12 induced gastric acid secretion in rats, and that this secretion peaked at about $30 \mathrm{~min}$ after injection. Moreover, Ohno et al. (8) stated that apelin-12 stimulates gastric acid secretion in vivo and increase histamine release from isolated ECL. The conflicting reports could be explained as resulting from differences in the form of apelin used, as the action of apelin peptide was found to be greatly influenced by its molecular size (28). apelin-13 which is the main form circulating in plasma, was showed to specifically bind to APJ receptor with a high affinity(42), and had greater biological activity than apelin-36 or apelin-17(43). Furthermore, apelin-12 has been reported to be more potent than Pyr1-apelin-13 in reducing blood pressure (28), and apelin 9, 10, and 11 have no effect on arterial blood pressure (28).In addition, it was reported that intracerebroventricular (i.c.v.) injection of apelin12 stimulates food intake during the day-time (44),while apelin 13 has no effect during day time(45).

As regard chronic administration of apelin-13 for 21 days in normal rats ,there was non significant change in gastric acid secretion, on chronic run, acute effect of apelin on gastric acid secretion may be counteracted by compensatory effects that increased gastric acid secretion like hypergastrinemia which is a physiological response to the reduction in gastric acid secretion $(\mathbf{4 6 , 4 7 )}$,gastrin stimulates release of histamine from ECL (48), activates the enzyme histidine decarboxylase (HDC) which is involved in histamine synthesis ( 49). Moreover, gastrin upregulates the expression of genes involved in histamine synthesis and storage $(\mathbf{5 0}, \mathbf{5 1})$. It has been proved that long-term gastric acid suppression for 14 days, induced hypergastrinemia and increase the number of ECL (52), in addition, 28 days of proton pump inhibitor treatment increased the blood gastrin level and the output of basal acid secretion by the development of parietal cells hyperplasia evoked by trophic action of gastrin(53). 
Another factor may help to antagonize the acute decreasing effect of apelin on gastric acidity in normal rats on chronic run is apelin effect on leptin level, leptin inhibited basal gastric secretion, gastrinemia, and mucosal gastrin mRNA in vivo(54), apelin-induced reduction in adiposity decreased leptin level $(\mathbf{5 5}, \mathbf{5 6})$ so help in increasing gastric acid secretion, and balanced the decreased acidity in normal rats.

chronic administration of apelin-13 for 21 days in both HFD and streptozotocin induced diabetic rats increased gastric acid secretion proved by significant decrease in $\mathrm{pH}$ and significant increase in both total and free acidity, and the percentage of increase of gastric acid secretion in HFD induced diabetic rats is more than streptozotocin induced diabetic rats. These effects may be through the effect of hypergastrinemia that balance on chronic run the acute effect of apelin on gastric acidity. In addition, in diabetic conditions, there is low levels of nitric oxide( NO) due to inhibition of nitric oxide synthase (NOS) by oxidative stress (57), this result in diabetic vascular complication which is a leading cause of a variety of neuropathy $(\mathbf{5 8 , 5 9 )}$ ).Alan et al.(34)stated that apelin increase expression of NOS and endothelial NO generation, which is one of the most potent endogenous vasodilators, anti-inflammatory, anti-proliferative and antithrombotic agent, it is widely recognized as an endogenous vasoprotective in diabetes $(\mathbf{6 0 , 6 1})$, in addition, many agents that increase nerve conduction velocity and reverse established neuropathy act through $\mathrm{NO}(62,63)$. By improvement of diabetic neuropathy, this effect cause increase in gastric acid secretion in HFD induced diabetic rats and streptozotocin induced diabetic rats when compared with control diabetic rats.

The present study revealed that chronic administration of apelin in HFD induced diabetic rats decreased insulin resistance and this effect is in line with the study of_Higuchi et al. (55) and Yue et al.(64) who reported that the high levels of circulating apelin found in HFD induced diabetic rats (65) help to delay the onset of insulin resistance, improvement of glucose tolerance test.

Apelin increase insulin sensitivity through modulating adiponectin level, as apelin induced reduction in adiposity increased adiponectin level $\mathbf{( 5 5 , 5 6 ) ,}$ adiponectin reverses insulin resistance and glucose intolerance in obese diabetic mice(66).Increasing insulin sensitivity by apelin help in improvement of neuropathy as 4 weeks of insulin therapy is able to successfully reversed established neuronopathy to control levels (67).
It is interesting that, in obese HFD induced diabetic rats, there is high level of leptin(68,69,70) ,with associated selective leptin resistance in hypothalamus, skeletal muscle, liver and pancreas with excess leptin action in non resistant tissue (71). leptin inhibited basal gastric secretion, gastrinemia, and mucosal gastrin mRNA in vivo (54), so hyperleptinemia present in obese diabetic rats cause excessive decrease in gastric acidity, apelin-induced reduction in adiposity decreased leptin level $(\mathbf{5 5 , 5 6 )}$ so help in increasing gastric acid secretion.

According to the effect of apelin on ghrelin level in gastric secretion, the present results stated that acute and chronic administration of apelin-13 decreased ghrelin level, in normal, HFD induced diabetic rats and streptozotocin induced diabetic rats, this effect may suggest presence of APJ receptors on ghrelin secreting cells(xla) cells and direct effect of apelin on ghrelin secretion.

According to the effect of apelin on pepsin level in gastric secretion, acute administration of apelin had no effect on pepsin level in all groups, while chronic administration of apelin caused significant decrease in pepsin level in gastric secretion. According to the effect of apelin on mucin content and $\mathrm{PH}$ of gastric mucosal surface, in all groups acute administration of apelin had no effect on mucin content while PH of surface gastric mucosa increase significantly, chronic administration of apelin caused significant increase in mucin content and $\mathrm{PH}$ of gastric mucosa in all groups, this suggest that apelin may have direct effect on mucous cells or may be due to the vasodilator effect of apelin (34), as appropriate microcirculatory blood supply helps to improve various lines of mucosal defence system in gastric mucosa (72, 73). Alan et al.(34)stated that the vasodilator effect of apelin is mediated predominantly by endothelial nitric oxide (NO) generation, it is known that NO plays a pivotal role in the regulation of gastric mucosal integrity through its action on the microcirculation and on the surface mucus bicarbonate barrier(74),moreover, $\mathrm{NO}$ is able to activate the cyclo-oxygenase (COX) pathway to enhance mucosal prostaglandin (PG)(75). Evidently, $\mathrm{PGE}_{2}$ plays a major role in the maintenance of the gastrointestinal tract integrity, repair of gastric mucosal injury and ulcer healing through induction of both cytoprotective bicarbonates and mucous glycoproteins (76).

As regard, the effect of apelin on volume of gastric secretion, acute and chronic administration of apelin cause significant decrease in volume of secretion in all groups, this may be attributed to 
the fact that apelin decrease intracellular water (77). There is evidence that apelin acts to counteract vasopressin (VP) actions through regulation of VP neurone activity and VP secretion $\quad \mathbf{( 7 8 , 7 9 , 8 0 , 8 1 ) . \quad E x o g e n o u s l y ~}$ administered apelin also reduced the amount of circulating VP and stimulated diuresis (79). In addition, apelin may act through NO which has reducing effect on volume of gastric secretion (82).

Another mechanism regarding the effect of apelin on volume of gastric secretion through the decreased ghrelin level as in the present study, there is positive correlation between ghrelin level and volume of gastric secretion in all studied groups.

In conclusion: Acute administration of apelin13 decrease gastric acidity, ghrelin level and volume of gastric secretion, increase of $\mathrm{PH}$ of gastric mucosal surface and cause no change of pepsin and mucin level in normal and diabetic rats, while chronic administration of apelin-13 for 21 days, caused no change in gastric acidity in normal rats, improve gastric acidity in diabetic rats, and decreased ghrelin level, pepsin level and volume of gastric secretion and increase $\mathrm{PH}$ of gastric mucosal surface and mucin level in normal and diabetic rats.

\section{REFERENCES}

1. Tatemoto, K.; Hosoya,M. andHabata, Y. (1998): Isolation and characterization of a novel endogenous peptide ligand for the human APJ receptor. Biochem.Biophys. Res. Commun., 251: 471-476.

2. Fan, X.; Zhou, N.; Zhang, X.andMukhtar, M.(2003). Biochemistry, 42:10163.

3. Lee, D. K.; Saldivia, V. R.and Nguyen, T. (2005). Endocrinology, 146: 231.

4. Habata, Y.; Fujii, R.andHosoya, M. (1999): Apelin, the natural ligand of the orphan receptor APJ, is abundantly secreted in the colostrums. Biochim.Biophys.Acta.,1452 : 25-35.

5. O'Carroll,A.M.; Selby, T.L.and Selby, M. (2000): Distribution of mRNA encoding B78/apj, the rat homologue of the human APJ receptor, and its endogenous ligand apelin in brain and peripheral tissues. Biochim.Biophys.Acta.,1492 : 72-80.

6. Wang, G.; Anini, Y.; Wei, W.; Qi, X. (2004):Apelin, a new enteric peptide: localization in the gastrointestinal tract, ontogeny, and stimulation of gastric cell proliferation and of cholecystokinin secretion. Endocrinol., 145: 13421348 .

7. Yakabi, K.; Ro, S. and Tanaka,T.(2004): Apelin stimulates acid secretion and histamine release in rat stomach. Gastroenterology, 126 (2) :1014.

8. Ohno, S.; Yakabi, K.; Ro, S.; Ochiai, M.; Onouchi, T.; Sakurada, T.; Takabayashi, H. and Takayama, K. (2012): Apelin-12 stimulates acid secretion through an increase of histamine release in rat stomachs. Regulat. Peptides, 174 (1-3): 71-78.

9. Lambrecht, N.W.G.; Yakubov, I.; Zer. C. and Sachs, G. (2006): Transcriptomes of purified gastric ECL and parietal cells: identification of a novel pathway regulating acid secretion. Physiological Genomics, 25: 153-165.

10. Nakamura, T.; Takebe, K.; Imamura, K.; Miazawa, T.; Ishii, M.; Kudoh, K. and Terada, A. (1994): Decreased gastric secretory functions in diabetic patients with autonomic neuropathy. Tohoku J. Exp. Med., 173 (2): 199-208.

11. Toth, C.; Brussee, V.; Martinez, J.A. (2006): Rescue and regeneration of injured peripheral nerve axons by intrathecal insulin. Neuroscience. 12;139 (2):429-449.

12. Hoybergs, Y.M and Meert, T.F. (2007): The effect of low-dose insulin on mechanical sensitivity and allodynia in type I diabetes neuropathy. Neurosci. Lett., 417(2):149-154.

13. McNay, E.C.; Ong, C.T.; McCrimmon, R.J. (2010): Hippocampal memory processes are modulated by insulin and high-fat-induced insulin resistance.. Neurobiol .Learn Mem., 93(4):546-553.

14. Nascimento, A.; Sugizaki, M.; Leopoldo, S.; LimaLeopoldo, A.; Nogueir,C.; Novelli, E.; Padovani C. and Cicogna, A.(2008): Misclassification probability as obese or lean in hypercaloric and normocaloric diet. Biol Res., 41: 253-259.

15. Cam, M.; Yavuz, O.; Guven, A. (2003): Protective effects of chronic melatonin treatment against renal injury in streptozotocin-induced diabetic rats. Pineal Res., 35(3): 212-220.

16. Chen,H.C.; Guh, J.Y; Chang, J. M.; Hsieh, M.C.(2005):role of lipid control in diabetic nephropathy.kidey int.,67(94):60-62.

17. Lin, Y.; Tseng, T.J.; Hsieh, Y.L. (2008): Depletion of peptidergic innervation in the gastric mucosa of streptozotocin-induced diabetic rats. Experimental Neurology, 213(2): 388-396.

18. Alumets, J.; Ekelund, M.; Håkanson, R. (1982): Gastric acid response to pylorus ligation in rats: is gastrin or histamine involved? J. Physiol., 323: 145156.

19. Bancroft J. D. and Stevens, A. (1982):Theory and Practice of Histological Techniques $.2^{\text {nd }}$ edition . Churchill-Livingstone, page 345.

20. Hawk, B.; Oser, L.; Bernard, L. (1947):Practical physiological chemistry. Philadelphia, Am. Journal, Med., vol. III, p. 779.

21. Kojima, M.; Hosoda, H.; Date, Y. (1999): Ghrelin is a growth-hormone-releasing acylated peptide from stomach. Nature, 402(6762):656-660.

22. Debnath, P.K.; Gode, K.D.; Das, D.G.; Sanyal, A.K. (1974): Effects of propranolol on gastric secretion in albino rats. Br. J. Pharmacol., 51(2):213-216.

23. Tietz, N.W.; Cook, T. and McNiven, M.A.(1995): Clinical Guide to Laboratory Tests, W.B. Saunders, Co., Philadelphia, 509-512.

24. Temple, R.C.; Clark, P.M. and Hales, C.N. (1992): Measurement of insulin secretion in type 2 
diabetes: problems and pitfalls. Diabetic Medicine 9: 503-512.

25. Matthews, D.R.; Hosker, J.P.; Rudenski, A.S.; Naylor, B.A. (1985): Homeostasis model assessment: insulin resistance and beta-cell function from

26. Sun, G.; Bishop, J.; Khalili, S.; Vasdev, S.; Gill, V.; Pace, D.; Fitzpatrick, D.; Randell, E.; Ya- Xie, G. and Zhang, H. (2007): Serum visfatin concentrations are positively correlated with serum triacylglycerols and down-regulated by overfeeding in healthy young men. Am J ClinNutr ., 85:399404.

27. Ladeiras-Lopes,R.; Ferreia-Martins, J.;LeiteMoreira, A.F. (2008):The apelinergic system: the role played in human physiology and pathology and potential therapeutic applications. Arq.Bras.Cardiol., 90: 343-349, 2008.

28. Tatemoto, K.; Takayama, K.; Zou, M.X.; Kumaki, I. (2001): The novel peptide apelin lowers blood pressure via a nitric oxide-dependent mechanism. Regul.Pept., 99: 87-92,

29. Susaki ,E ; Wang, G. andCao, G. (2005): Apelin cells in the rat stomach.Regulatory Peptide, 129(3): 37-41.

30. Masuda, Y.; Tanaka, T.; Inomata, N. (2000): Ghrelin stimulates gastric acid secretion and motility in rats. Biochem.Biophys. Res. Commun., 276: 905-908.

31. Date, Y.; Nakazato, M.; Murakami, N. (2001): Ghrelin acts in the central nervous system to stimulate gastric acid secretion. Biochem.Biophys.Res. Commun., 280: 904-907.

32. Hersey, S.J and Sachs, G. (1995): Gastric acid secretion. Physiol Rev., 75(1):155-189.

33. Kitano, M.; Norlén, P.; Ding, X.Q.; Nakamura, S. (2000): Long-lasting cholecystokinin(2) receptor blockade after a single subcutaneous injection of YF476 or YM022. Br. J. Pharmacol., 130(3):699705.

34. Alan, G.; Nicholas, L ; David, A.B. (2008): Vascular Effects of Apelin In Vivo in Man. J. American college of cardiology, 52(11):908-913.

35. Pisarenko, O.I.; Serebriakova, L.I.; Pelogeřkina, Iu.A.; Studneva, I.M. (2012): Involvement of NOdependent mechanisms of apelin action in myocardial protection against ischemia/reperfusion damage. Kardiologiia, 52(2): 52-58.

36. Martinez-Cuesta, M.A.; Barrachina, M.D. (1992): The role of nitric oxide and platelet-activating factor in the inhibition by endotoxin of pentagastrin-stimulated gastric acid secretion. Eur. J. Pharmacol., 218: 351-354.

37. Brown, J.F.; Hanson, P.J. and Whittle, B.J.R. (1993): The nitric oxide donor,S-nitroso-Nacetylpenicillamine, inhibits secretory activity in rat isolated parietal cells. Biochem.Biophys. Res. Commun., 195: 1354-1359.

38. Kitamura, M.;Sugamoto,S.;Kawauchi, S.; Kato, S. (1999): Modulation by endogenous nitric oxide of acid secretion induced by gastric distention in rats: enhancement by nitric oxide synthase inhibitor. J. Pharmacol. Exp. Ther., 291: 181-187.

39. Berg, A.; Redeen, S.; Ericson, A. C.; Sjöstrand,S.E. (2004):Nitric oxide-an endogenous inhibitor of gastric acid secretion in isolated human gastric glands. Gastroenterol ., 6:4-16.

40. Hrinchenko,O.A.andIanchuk,P.I. (2012: The role of nitric oxide and taurine in regulation of dogs gastric secretory function. Fiziol.Zh., 58(6):48-56.

41. Shibata, N.; Matsu, H ; Yokota, T. (2006): Direct effects of nitric oxide on histamine release from rat enterochromaffin-like cells. Eur J Pharmacol., 535(1-3):25-33.

42. Hosoya,M.;Kawamata, Y.; $\quad$ Fukusumi, S.(2000):Molecular and functional characteristics of APJ tissue distribution of mRNA and interaction with the endogenous ligand apelin. J. Biol. Chem., 275: 21061-21067.

43. Kawamata,Y.;Habata,Y.; Fukusumi, S.(2001):Molecular properties of apelin: tissue distribution and receptor binding. Biochim.Biophys.Acta, 1538: 162-171.

44. O'Shea,M.; Hansen, M.J.; Tatemoto, K. (2003): Inhibitory effect of apelin-12 on nocturnal food intake in the rat. Nutr.Neurosci., 6: 163-167.

45. Shuang, Y.; Yang, Y .; Qin, Y. (2012): Central apelin-13 inhibits food intake via the CRF receptor in mice. Peptides, 33(1):132-138.

46. Schenk, B.E.; Kuipers, E.J.; Klinkenberg-Knol, E.C.; Bloemena, E. (1998): Hypergastrinaemia during long-term omeprazole therapy: influences of vagal nerve function, gastric emptying and Helicobacter pylori infection. Aliment.Pharmacol.Ther., 12: 605-612.

47. Alan, B.R. ; Michel, D.; Kassam, N. (2010): Safety of the long-term use of proton pump inhibitors. World J. Gastroenterol., 16(19): 2323-2330,

48. Sandvik, A.K.; Waldum, H.L.; Kleveland, P.M. (1987): Gastrin produces an immediate and dosedependent histamine release preceding acid secretion in the totally isolated, vascularly perfused rat stomach. Gastroenterol ., 22(7):803-808.

49. Sandvik, A.K.; Dimaline, R.; Mårvik, R. (1994): Gastrin regulates histidine decarboxylase activity and mRNA abundance in rat oxyntic mucosa. Am. J Physiol., 267(2): 254-258.

50. Dimaline, R and Sandvik, A.K. (1991): Histidine decarboxylase gene expression in rat fundus is regulated by gastrin. FEBS Lett., 281(1):20-22.

51. Dimaline, R and Struthers, J. (1996): Expression and regulation of a vesicular monoamine transporter in rat stomach: a putative histamine transporter. J. Physiol., 490 (1):249-256.

52. Kimura, K.; Chen, D.; Lindström, E. (1997): Functional impairment of the individual rat stomach ECL cell in response tosustained hypergastrinemia. Regulat. Peptides, 72 (2-3): 69-77.

53. Tsyriuk,O.I. (2011): Correction of negative influence of long-term hypergastrinemia on gastric acid secretion. Fiziol. Zh., 57(1):66-71.

54. Goïot, H.; Attoub, S.; Kermorgant, S. (2001): Antral mucosa expresses functional leptin receptors 
coupled to STAT-3 signaling, which is involved in the control of gastric secretions in the rat. Gastroenterol.,121 (6): 1417-1427.

55. Higuchi, K.; Masaki, T.; Gotoh, K. (2007):Apelin, an APJ Receptor Ligand, Regulates Body Adiposity and Favors the Messenger Ribonucleic Acid Expression of Uncoupling Proteins in Mice. Energy Balance/Obesity, 148 (6): 2690.

56. Naderali, E.K.; Fatani, S .; Telles, M. (2008): The effects of physiological and pharmacological weight loss on adiponectin and leptin mRNA levels in the rat epididymal adipose tissue. EurJ Pharmacol., 579(1):433-438.

57. Beltowski,J.;Kêdra,A.(2006):Asymmet-ric dimethylarginine (ADMA) as a target for Pharmacotherapy. Pharmacol. Rep., 58 :159-178

58. Brownlee,M.(2001):Biochemistry and molecular cell biology of diabetic complications. Nature, 414: 813-820.

59. Yamagishi,S.andImaizumi,T.(2005): Diabetic vascular complications: pathophysiology, biochemical basis and potential therapeutic strategy. Curr. Pharm. Des., 11: 2279-2299.

60. Mariotto, S.; Menegazzi, M. and Suzuki, H. (2004):Biochemical aspects of nitric oxide. Curr. Pharm. Des., 10: 1627-1645.

61. Groop, P.H.; Forsblom, C. and Thomas, M.C. (2006): Mechanisms of disease: pathway-selective insulin resistance and microvascular complications of diabetes. Nat. Clin. Pract. Endocrinol. Metab., 1: 100-110, 2006.

62. Cameron, N.E and Cotter, M.A. (1996): Rapid reversal aminoguanidine of the neurovascular effects of diabetes in rats: modulation by nitric oxide synthase inhibition._Metabolism, 45(9):11471152.

63. Cotter, M.A and Cameron, N.E. (1998): Correction of neurovascular deficits in diabetic rats by beta2adrenoceptor agonist and alpha1-adrenoceptor antagonist treatment: interactions with the nitric oxide system. Eur J Pharmacol., 343(2-3):217-23.

64. Yue, P.; Jin, H.; Aillaud, M.; Deng, A.C. (2010): Apelin is necessary for the maintenance of insulin sensitivity. AJP . Endo., 298 (1): 59-67.

65. Boucher, J.; Masri, B.; Daviaud, D.; Gesta, S. (2005): Apelin, a newly identified adipokine upregulated by insulin and obesity. Endo., 146 (4): 1764-1771.

66. Yamauchi, J.; Kamon, H.; Waki , S. (2001): The fat-derived hormone adiponectin reverses insulin resistance associated with both lipoatrophy and obesity. Nat. Med., 7: 941-946, 2001.

67. Robert, E.S.; Feng, D.; Wang, Q. (2011): Effect of Insulin and anErythropoietin-Derived Peptide (ARA290) on Established Neuritic Dystrophy and Neuronopathy in Akita (Ins2Akita) Diabetic Mouse Sympathetic Ganglia. Exp. Neurol., 232(2):126135.

68. Paolisso, G.; Tagliamonte, M.R.; Galderisi, M. (1999): Plasma leptin level is associated with myocardial wall thickness in hypertensive insulinresistant men. Hypertension, 34: 1047-1052.
69. Naderali, E.K.; Brwon, M.J.; Pickavance, L.C. (2001): Dietary obesity in the rat induces endothelial dysfunction without causing insulin resistance: a possible role for triacylglycerols. Clin. Sci., 101: 499-506.

70. Derosa, G.; Fogari, E.; D'Angelo, A.; Bianchi,L.(2013):Adipocytokine Levels in Obese and Non-obese Subjects: an Observational Study. Inflammation.

71. Seth, S.; Qasim,A ; Muredach, P. (2008): Leptin Resistance: A Possible Interface of Inflammation and Metabolism in Obesity-Related Cardiovascular Disease. J. American college of cardiology, 52(15):1201-1210.

72. Holzer, P. (2000) : Gastroduodenal mucosal defense. Curr. Opin. Gastroenterol., 16(6): 469-78.

73. Konturek, P.C. and Konturek, S.J. (2003): The history of gastrointestinal hormones and the Polish contribution to elucidation of their biology and relation to nervous system. J. Physiol. Pharmacol., 54 (3): 83-98.

74. Whittle, B.J.(1994):Nitric oxide in gastrointestinal physiology and pathology. L.R. Johnson (Ed.), The physiology of the gastrointestinal tract, Raven Press, New York, pp. 267-294.

75. Cho, C.H. (2001): Current roles of nitric oxide in gastrointestinal disorders. J. Physiol. Paris, 95 (16): 253-256.

76. Wallace, J.L. and Granger, D.N. (1996): The cellular and molecular basis of gastric mucosal defense. FASEB J., 10 (7): 731-740.

77. Kazancioglu, R.; Gursu, M.; Karadag, S. (2012): Volume status in patients on peritoneal dialysis: the role of apelin and bio-impedance spectroscopy. Ren Fail., 34 (9): 1068-73.

78. Reaux, A.; De Mota, N.; Skultetyova, I. (2001): Physiological role of a novel neuropeptide, apelin, and its receptor in the rat brain. J. Neurochemis., 77: 1085-1096.

79. De Mota, N.; Reaux-Le Goazigo, A.; El Messari, S.; Chartrel, N. (2004): Apelin, a potent diuretic neuropeptide counteracting vasopressin actions through inhibition of vasopressin neurones activity and vasopressin release. PNAS, 101: 10464-10469.

80. Reaux-Le Goazigo, A.; Morinville, A.; Burlet, A. (2004): Dehydration-induced cross-regulation of apelin and vasopressin immunoreactivity levels in magnocellular hypothalamic neurones. Endocrinol., 145: 4392-4400.

81. Azizi, M.; Iturrioz, X.; Blanchard, A. (2008): Reciprocal regulation of plasma apelin and vasopressin by osmotic stimuli. J. Am. Soc. Nephrol., 19: 1015-1024.

82.Hrinchenko, O.A. and Ianchuk PI. (2012): The role of nitric oxide and taurine in regulation of dogs gastric secretory function. Fiziol. Zh., 58(6):48-56. 


\section{تاثيرأبلين r ا على العصارة المعدية فى الجرذان الطبيعية و المصابة بداء السكرى}

إن هرمون الأبلين من الهرمونات البيتيدية المُكتشفَفِة حديثاً، والتي وُجد أن لها تأثتيرات مختلفة على الجهاز الدوري ، و الغدة النخامية وتحت

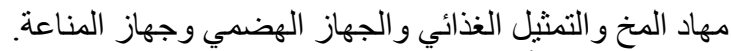

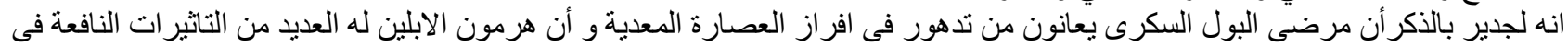

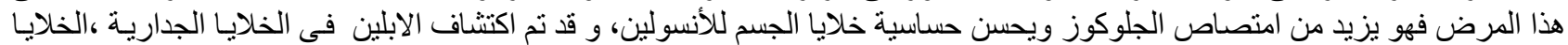

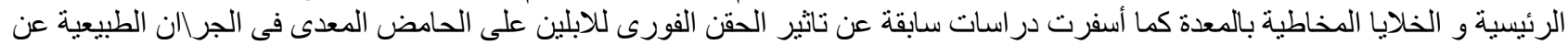

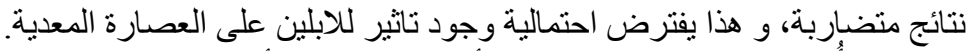

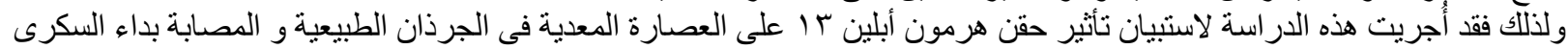

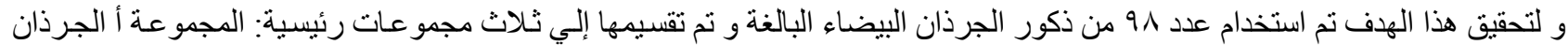

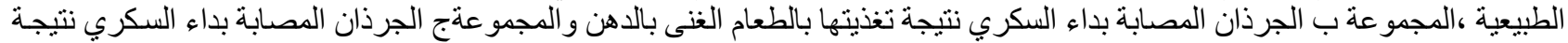

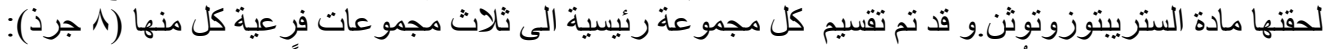

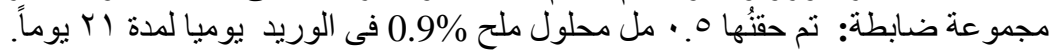

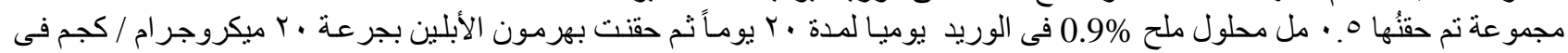

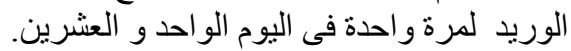

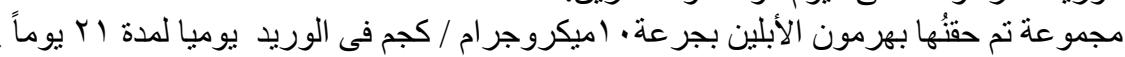

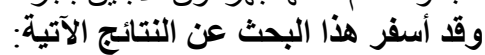

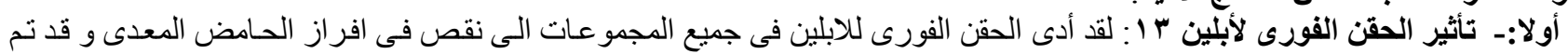

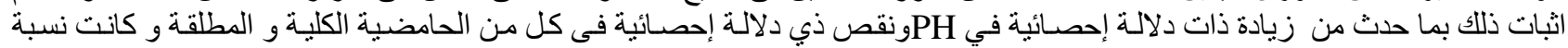

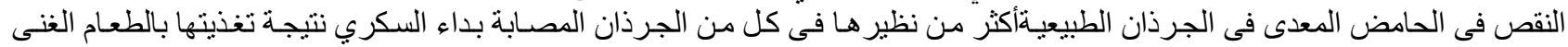

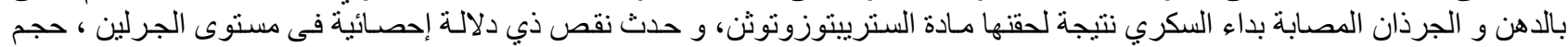

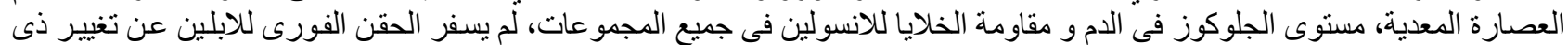

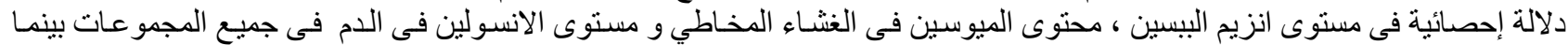

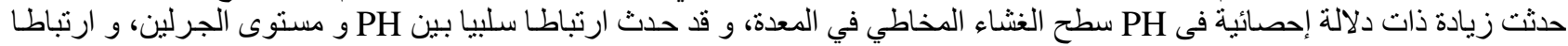

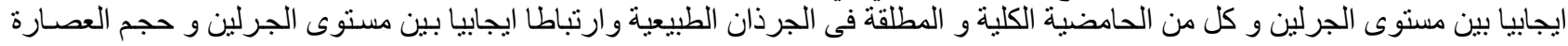

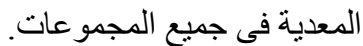

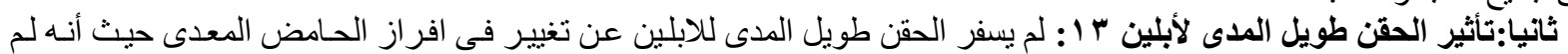

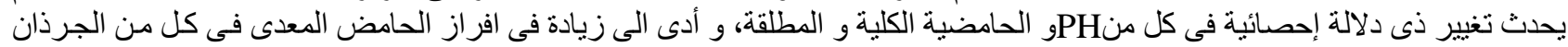

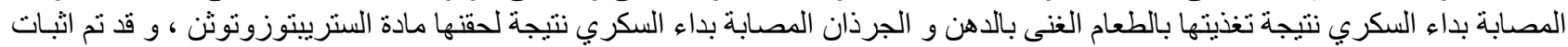

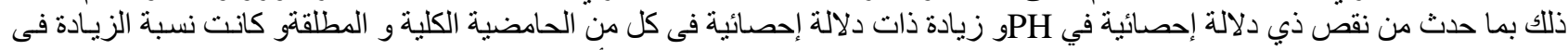

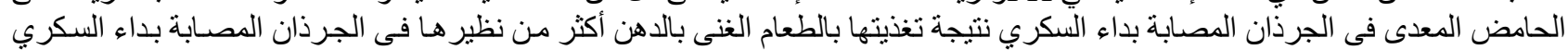

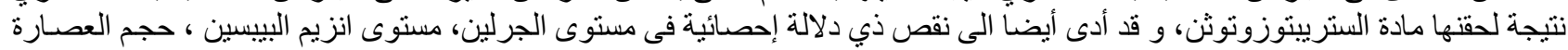

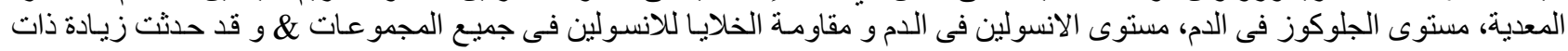

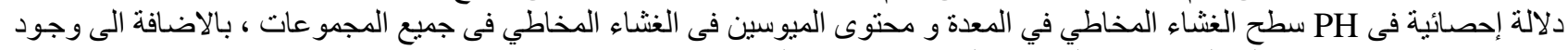

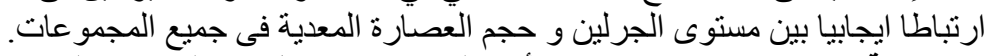

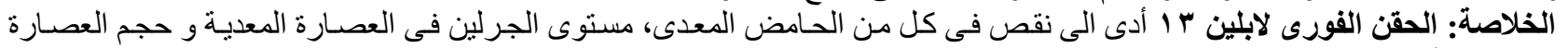

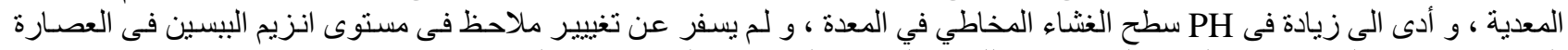

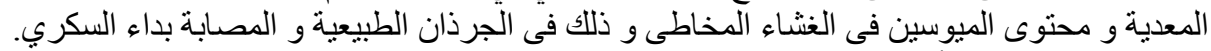

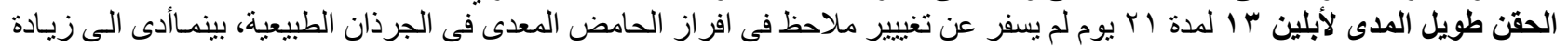

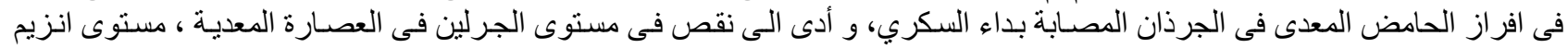

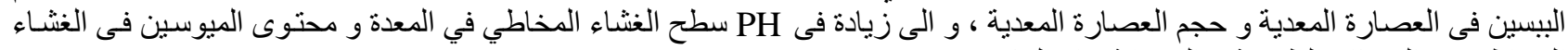

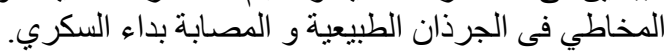

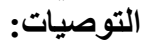

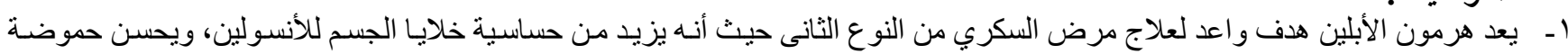

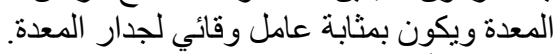

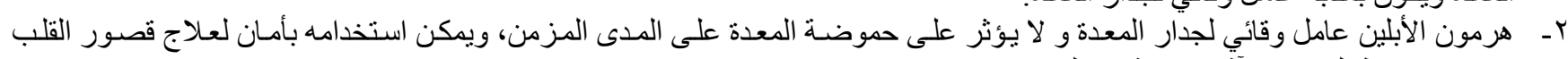

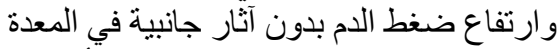

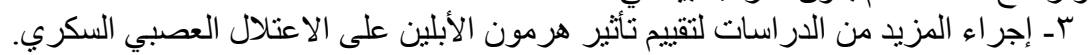

